結核性リンパ節炎の 1 例

\author{
尾崎登喜雄・福冨 剛・領家和男・駒井正・浜田兓
}

\title{
Report of a case of tuberculous lymphadenitis
}

Tokio Osaki - Tsuyoshi Funutom - Kazuo Ryoke - Tadashi Komai - Takeshi Hamada

結核性リンパ節炎は1，一般に肺結核の既往歴のある 青少年, すなわち15〜30歳に多く併発するとされている が，今回わたくしたちは，4歳の小児で胸部をはじあ身 体他部には病巣が認められなかったにもかかわらず，1 次性に額下部括よび上頸部の結核性リンパ節炎の1例を 経験したので，その概要を報告する。

\section{症例}

患 者：【(昭和 47 年 4 月曰日生, 男). 当科初診：昭和 51 年 4 月曰日.

主 訴 : 右額下部の腫脹.

家族歴：同居の祖父，昭和51年 2 月口日，胸部結核症 にて療養所へ入院。注かの家族には異常は認められなか った。

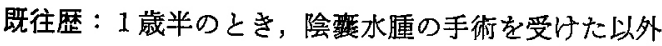
は特記事項なし。

現病歴：昭和51年 3 月回日ごろから風邪をひき，38.5 ${ }^{\circ} \mathrm{C} \sim 40^{\circ} \mathrm{C}$ の発熱が $2 \sim 3$ 日続いた。 3 月日日ごろから 右䪽下リンパ節がわずかに腫脤したので, 某開業医受診, 流行性耳下腺炎之診断され，その処置を受けた。 3 月 日ごろより右内眼角部の発赤・睡脹を認め,これらは次 第に著明となり，流涙も加わったため，3 月目某眼科 医受診ただちに当院眼科を紹介された，㐋こで急性淡 䨟炎の診断下に切開・洗浄処置を受け，相当の症状軽減

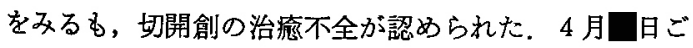
ろより右頸下部の腫脹は一段と增大し，硬結を認めるよ らになったため，4月回当院耳鼻咽喉科を紹介され， 口腔内にら崡があったことから，5歯によるりンパ腺症 を疑われ，当科に4月口日紹介された，

現 症：体格は標準より軽度に劣るる，特に異常はな

鳥取大学医学部附属病院绦科口腔外科（主任：浜田 穘教授)

Tottori University, School of Medicine Department of Oral Surgery (Chief: Prof. Takeshi Hamada)

受付日：昭和53年 3 月 3 日

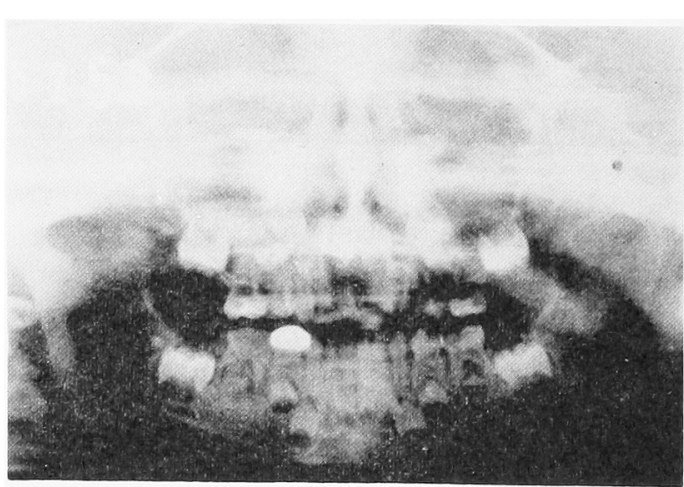

図 1 昭和 51 年 4 月【日，初診時のパノラマ学真, $\overline{\mathrm{D}}$ に乳菌冠が装着してあり， $\mathrm{E} \mid$ は米冠崩㯰し，根 尖病集がみられる。はかに㤨常所見はみられ ない.

く，栄養状態は普通であった，口腔内についてみると， $\overline{\mathrm{E}} \mid$ は米冠崩壊し， $\overline{\mathrm{D}} \mid$ には乳米冠が装着されていたが， 電肉にはさしたる所見は認められなかった。一方，口蓋 扁桃は腫脹しているものの発赤はなく，唾液の分泌は正 常であった。

耳介前部に小指頭大の可動性リンパ節を1個触知で き，耳介下部には拇指頭大で可動性りンパ節，さらに顎 下部にも拇指頭大のリンパ節がそれぞれ1個ずつ認めら れ、これらの腫大したリンパ節は比較的硬かった。なお 身体他部にはリンパ節は触知できなかった。

処置ならびに経過：オルンパントモ写真で $\bar{E} \mid$ に根尖 病巣を認め(図 1)，罘下部をはじめとするリンパ腺症は， この根尖病单による资症性反応とも考元られたため， $\mathbf{E}$ の根管治療を行い，腫大したリンパ節に対し，赤外線療 法および抗生物質投与を行うも，症状怪軽快せず，根管 状熊が不良のため，5月日日， Elを抜去した。しかし ながら，眼科で 3 月日日受けた右内眼角部の切開創は 発赤したままであり，重大したリンパ節の改善は得られ なかった。このため，悪性リンパ腫・特殊性炎・膠原病 など種々の疾患を疑い，スクリーニングのため、アミラ 


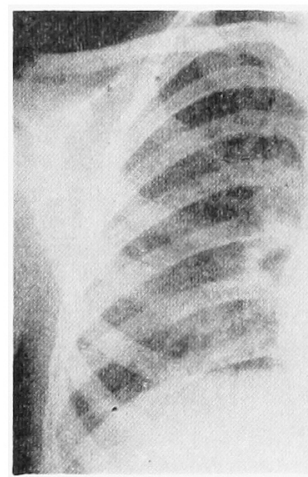

図 2 められない。

表 1 諸検査結果

\begin{tabular}{|c|c|c|c|}
\hline \multicolumn{2}{|l|}{ 血液一般 } & \multicolumn{2}{|c|}{ フミラーゼ 87} \\
\hline W.B.C. & 10,200 & ASLO & 40 \\
\hline R.B.C. & $455 \times 10^{4}$ & $\mathbf{R}-\mathbf{A}$ & $(-)$ \\
\hline $\mathrm{Hb}$ & 10.7 & CRP & $(-)$ \\
\hline $\mathrm{Ht}$ & 32.7 & LE & $(-)$ \\
\hline 血小板 & $8.1 \times 10^{4}$ & ESR & $1 \mathrm{H} \ldots \ldots \ldots 64$ \\
\hline 血液生化学 & & & $2 \mathrm{H} \cdots \cdots \cdot 100$ \\
\hline $\mathrm{Na}$ & 140 & & 平均……5. \\
\hline $\mathbf{K}$ & 4.1 & ッ反 & $19 \times 20$ 硬結 \\
\hline $\mathrm{Cl}$ & 109 & 白血球S & 類 \\
\hline Protein & 7. 149 & $\mathrm{Ba} \cdots 0$ & $\operatorname{Seg}_{2} \cdots 16$ \\
\hline $\mathrm{A} / \mathrm{G}$ & 1. 34 & Eo $\cdots 0$ & $\mathrm{Seg}_{3} \cdots 26$ \\
\hline BUN & 9 & $\mathrm{Me} \cdots 0$ & $\operatorname{Seg}_{4} \cdots 1$ \\
\hline Ch-E & 1.02 & Stw5 & Ly $\cdots 59$ \\
\hline Al-phos & 28 & & Mo $\ldots 2$ \\
\hline $\mathrm{LDH}$ & 458 & & \\
\hline GPT & 24 & & \\
\hline GOT & 32 & & \\
\hline
\end{tabular}

一ぜ・ASLO - CRP · LE · RA · 血液一般 - 血液生化学 - ESR ・ツベルクリン反応・白血球分類・胸部X線写真 撮影など諸検查を笑施した(表1)。胸部X線写真では (図 2)，異常所見は認められなかったが，ESR は1時 間值 $64 ， 2$ 時間値 100 , 平均57 と著明に元進し, ッ反で は19×20mm 硬結を呈したことにより，結核症を疑い； 確定診断を得るために靧下リンバ節の試切を 行った. 鏡検により，多数の核が胞体の边縁に並んだ ングハンスの巨細胞が散見され，その周国には乾性境死 が認められ，その外周にリンパ球の強い浸潤，また類上 皮細胞す琹められたので、リンハ節結核症と確定診断し た(図 3，4).

全身療法は小览科へ依頼し，局所の瀵察は当科で行う こととし，外来にて SM，INH 投与を開始した。陚切

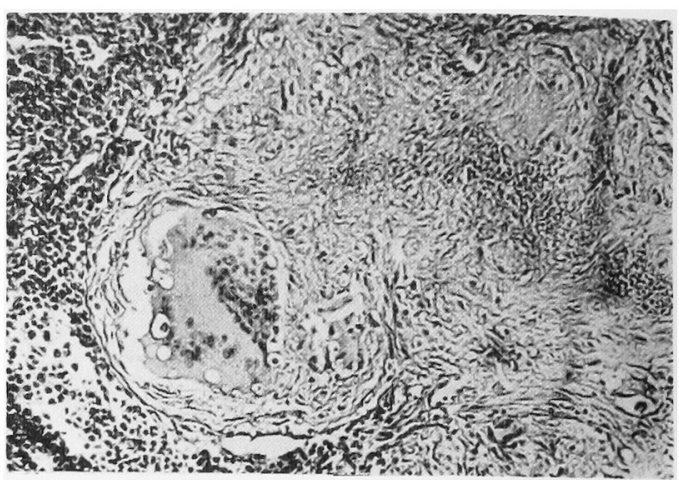

图 $3 \mathrm{H} \cdot \mathrm{E}$ 染色 $\times 100$ ，ランダハンスの巨細胞がみら れ，その周囲には乾性壊死・リン八球の強い浸潤 がみられる。

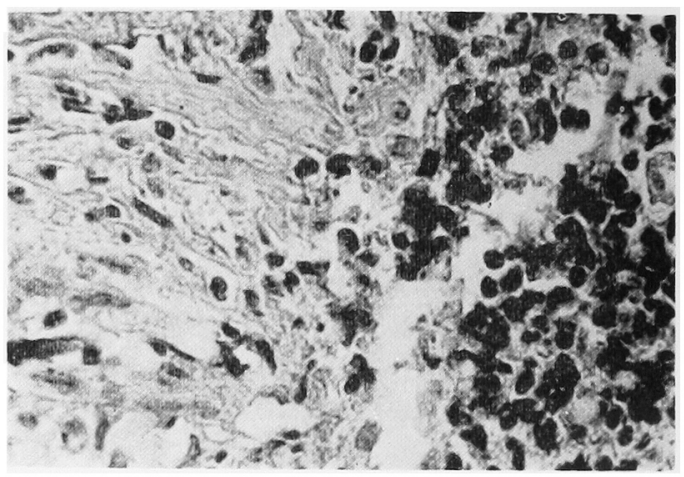

図 $4 \mathrm{H} \cdot \mathrm{E}$ 染色 $\times 400$ ，類上皮細胞がみられる。

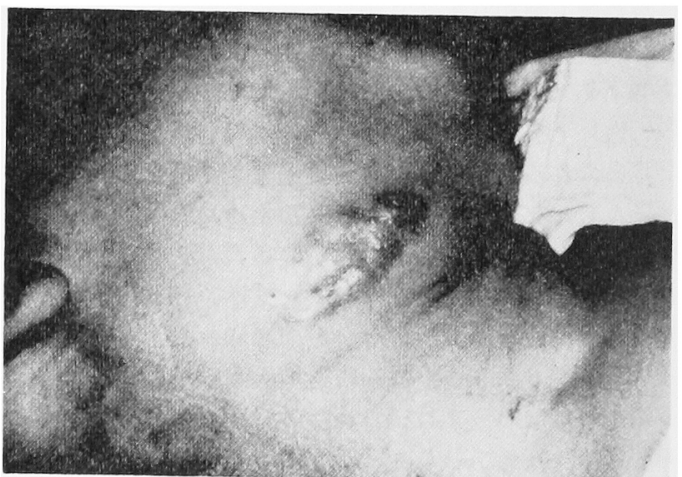

図 5

試切後20日，佱が哆開しはし めている.

後 1 週間目に抜系したが，ますなく哆開しはじめ，排膿 も著明となり(図 5)，膿の細菌榆查により結核菌が証明 され，さらに咽頭からも結核菌が証明されたため,

入院の上，加療することとなった（图 9).

入院隔離後，SM，INH，PAS の3 者療法が続けら 


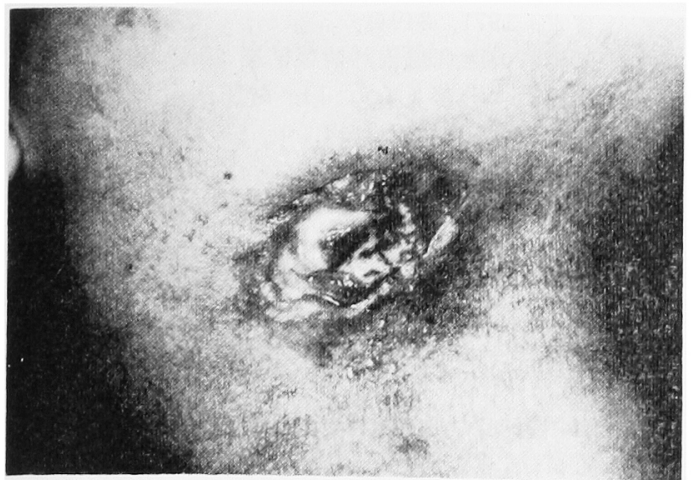

图 6 大院時の試切創の所見。

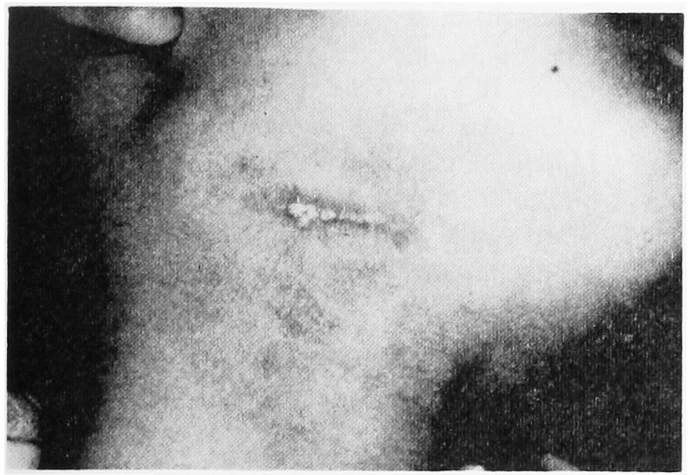

图 7 ，退院15日前の所見。陊開した 試切創は完全に上皮化している。

れ，創は次第に治癒の傾向をみせ，尰大したリンパ節も 徐々にではあるが，縮小しはじめ， ，試切創は 完全に上皮化した(図 7)。，退院させ，現在す 外来にて経過観察中であるが， の胸部X線写真 においても異常所見は認められない（図8）。

\section{考}

\section{察}

結核症による死亡は，昭和10年から25年までの間は死 因の第 1 位を，27年までは第 2 位を占めていたが，抗生 物質の出現, 普及以後だんだん減少し, 昭和 47 年には第 10 位となっている ${ }^{2}$ ，当時は，口腔への 2 次感染も比較 的多くみられたものと思われるが，最近は非常にまれと なっている，昭和48年—現在の厚生省の報告3)を みると，昭和 47 年年末報告の結核登録者総数 923,149 人 のちち，78,693人 $(8.5 \%)$ を無作為に抽出し, その内容 を調查したものによると，肺外結核は 5,073 人(6.4\%)と 非常に少ない，しかしながらこのうちリンパ節結核は 1,606人 (31.7\%) と比較的多く，そのなかで 0〜14歳が 310 人 (19.3\%) を占めている.このことより, 結核症の

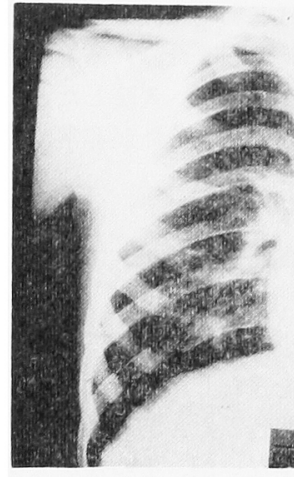

図 8

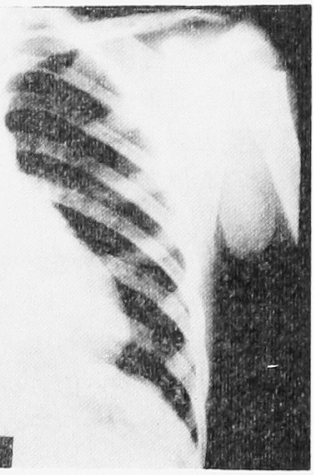

, 退院後 3 か月の胸部X線 写真. 異常院影は認められない。

なかでリンパ節結核は少ないが，若年齢凮ではリンパ節 結核症が多くを占めていることがらかがえる。一般に口 腔領域の結核症は，肺拉よび他部からの感染による2次 結核症がほとんどであり，顎下部执よび上頸部のリンバ 節についてみると，中村りは顎下部技よび頸部リンパ 節，特に上深頸リンパ節に多いとあり，また，Popescu V.ら`は買下リンパ節扣よび頸部リンパ節が扣かされた 場合，ほとんぞ 2 次感染であり，舌・口蓋・扁桃などの 原発病栄に続発するものであると述べている。これに対 して，本症例は口腔粘膜・扁桃・肺など身体他部には長 期間の観察にもかかわらず，異常は見い出し得ず，沃栾 炎に対する切開創の治瘜不全扣よび上頸部ならびに顠下 リンパ節の尰大のみが認められたにすきなかった，内眼 角部の切開創部の生検は行っていないものの, 創の肉眼 所見からすると，明らかに結核性の肉芽を思わしめ，枵 下部・頸部リンパ節の消長と創の治瘜とが一致したこと からすると，沃整炎す結核性であったと思われる。これ らの所見からすると，眼部，あるいは堮頁下・上頸部リン パ節のいずれかが初発感染をきたしたものと考えられる が，涋衰炎の発症とリンパ節の腫大はほぼ同一時期にみ られたことより，どららが初発かは断定し得ない：涋势 と靧下・上頸部リンパ節の解剖学的位置関俰からする と，眼部に初発感染をきたしたと考えた方が妥当のよう にす思われる、いずれにしてす結核症としてはまれなる のであるち. 感染経路についてみると，祖父からの飛沫 ・経口感染によると推察され，仮にリンパ節が初発感染 栄であったとするならば，多くの成畫1,5 9)論文に記載さ れているよらに，ワルダイェルの咽頭りンパ環を経てリ ンパ節への感染をきたしたるのと推察される。また， $\overline{\mathrm{E}} \mid$ のら畨和よび根尖病策からの感染も全く否定できな いと考えられたため, 根尖病栄の組織学的㭘索を行った が，根尖部には結核病巣は諗められなかった。

結核性リンパ節炎の報告例 ${ }^{10}$ はわずかであり，日常の 臨床に扣いてる，とかく見逃しやすいことと思われる。 
実際，われわれもあとになり，はじめて家族より知り得 たものの，家族歴について初診時問診した際，本患者発 症の 1 か月前に祖父が肺結核症で療養所へ入院したとい ら事実を得ることができなかったため, 診断が非常に遅 れた点を反省しなくてはならないであろら。

\section{お り に}

今回わたくしたちは，4歳の小児で, 涙裂あるいは顎 下部・頸部リンパ節に初発感染をきたしたと思われる 1 例を経験したので，その概要を報告した，肺外結核が結 核のなかで占める割合は非常に少ないが，そのなかでリ ンパ節結核は比較的多い。なかでも小睍には比較的多く 出現する。疼痛などの自覚症状がない場合が多いので注 意を要すると思われる。

な扰，本症例の要旨は第31回日本口腔科学会総会に拉 いて発表した。

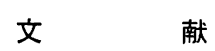

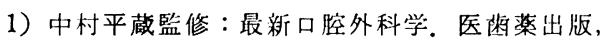

東京, 1971, 849頁.

2) 厚生省大臣官房統計悄報部編：昭和 49 年人口動 態統計 上巻 (Vol. 1). 財団法人 厚生統計協 会, 東京, 1977, 76頁.

3）島尾忠男編：「結核おょび呼吸器疾患文献の抄 録速報」, 25-11，25-12，財団法人結核予防会， 1973，539頁, 590頁.

4) Popescu, V., Stieber, C.: A clinical and therapeutical contribution to the study of submandibular tuberculous lymphadenopathies. Minerva Stom 20: 651971.

5) 石川梧朗, 秋吉正豊 : 口腔病理学 II. 永末書店, 京都, 1973，636頁。

6) 大塚貞光: 新外科学概説. 医菌薬出版, 東京, 1972，323頁.

7) 石川梧朗, 他 : 新菌学大辞典. 永末書店, 京都, 1970，204面.

8) 医学大辞典, 南山堂, 東京, 1975, 397頁.

9) Colby, R.A., Kerr, D.A., Robinson, H.B.G.: Color atlas of oral pathology III. ed, J. B. Lippincott Co., Philadelphia Toronto, 1971, p 112.

10) Sear, A.J.: Tuberculous lymph nodes and dental infection. Brit J Oral Surg 8:91 1970. 